\title{
Comparison of Bovine Pericardium Decellularization Protocols for Production of biomaterial for Cardiac Surgery
}

\author{
A. A. Sokol ${ }^{1}$, D. A. Grekov ${ }^{1}$, G. I. Yemets ${ }^{1}$, A. Yu. Galkin ${ }^{2}$, N. V. Shchotkina ${ }^{1}$, \\ A. A. Dovghaliuk ${ }^{1}$, O. V. Telehuzova ${ }^{1}$, N. M. Rudenko ${ }^{1}$, O. M. Romaniuk ${ }^{1}$, I. M. Yemets ${ }^{1}$ \\ ${ }^{1}$ Scientific and Practical Medical Center for Pediatric Cardiology and Cardiosurgery \\ of the Ministry of Health of Ukraine \\ 24, Yuriia Illienka Str., Kyiv, Ukraine, 04050 \\ ${ }^{2}$ National Technical University of Ukraine "Igor Sikorsky Kyiv Polytechnic Institute" \\ 37, Pobedy Av., Kyiv, Ukraine, 03056 \\ cardiotissue@gmail.com
}

\begin{abstract}
Aim. Determination of the most effective protocol for decellularization of the bovine pericardium. Methods. Bovine pericardium was decellularized following five protocols: group $1-$ Ammonium Hydroxide + Triton X-100, group 2-1\% SDS + Ammonium Hydroxide - Triton $\mathrm{X}-100$, group $3-1 \% \mathrm{SDS}$, group $4-$ Trypsin enzyme $+1 \%$ SDS, group $5-0,1 \% \mathrm{SDS}$, respectively. Histological, biomechanical properties and detection of nucleic acids concentration in the samples were studied. Results. The decellularization time for groups 1 and 2 is much longer than described in previous scientific publication. Also, the biomechanical properties were lower than in the samples of control group. The lowest results were observed in the samples of group 3. Though in this group we observed the almost complete removal of cells from the tissues, unfortunately biomechanical properties of pericardium were lost. The samples of group 4 and 5 have high tissue tensile strength, the absence of nucleic acid after 21 days of decellularization. Conclusion. The data of histological, biomechanical and DNA testing showed that the protocols with $0,1 \%$ SDS and Trypsin enzyme $+1 \%$ SDS are optimal for the procedure of decellularization.
\end{abstract}

Keyw ord s: pericardium, decellularization, tissue engineering

\section{Introduction}

Cardiovascular diseases are the most common cause of adult morbidity and mortality for many decades. It is astonishing that over 300,000 heart valve replacements and over
570,000 arterial bypasses are performed worldwide annually [1]. Therefore, to cover the gap between facilities' capacity and the number of patients in need of medical devices and pro-

(C) 2020 A. A. Sokol et al.; Published by the Institute of Molecular Biology and Genetics, NAS of Ukraine on behalf of Biopolymers and Cell. This is an Open Access article distributed under the terms of the Creative Commons Attribution License (http://creativecommons.org/licenses/by/4.0/), which permits unrestricted reuse, distribution, and reproduction in any medium, provided the original work is properly cited 
cedures, numerous approaches in multiple branches of the biomedical sciences are designed in order to cope with the challenge of developing well-recognized materials for cardiovascular repair. This field is consequently becoming an important flagship for transplantation medicine.

Estela de Oliveira Lima et al. [2], described the decellularization of tissues and organs from human or animal donors as a process of ensuring immunologic safety and preservation of basic structural and functional components of extracellular matrix, such as proteins, collagen and glycosaminoglycans (GAGs). The issue of decellularization methods has received considerable critical attention. Given the decellularization of bovine pericardium as a natural scaffold is a promising approach for production of bioprosthetic cardiac valves and patches in cardiac surgery and in the field of tissue engineering and regenerative medicine [3].

The concept of extracellular matrix (ECM) isolation of cells from native tissues in order to produce a natural scaffold is a main goal of the decellularization. The key roles belong to the alloreactivity and prevention of a transplant. In light of recent events, an effective way to reduce the immunogenicity in the posttransplant period and, as a consequence, to prolong functional usefulness is to decellularize the tissue in different ways. However, the key mechanisms of realization of the recipient's immune reactivity during the implantation of cell-free biomatrix have not been established.

The aim of this study was to evaluate the effectiveness of cell removal, preservation of extracellular matrix properties and mechanical integrity of the decellularized bovine pericar- dium, using five different protocols, previously described in the literature.

\section{Materials and methods}

Bovine pericardium was decellularized according to five protocols: group 1 - Ammonium Hydroxide + Triton X-100, group 2-1\% SDS + Ammonium Hydroxide - Triton X-100, group $3+1 \%$ SDS, group $4-$ Trypsin enzyme $+1 \%$ SDS, group $5-0,1 \%$ SDS, respectively. Untreated pericardium was used as a primary control sample. We performed the complex histological examination, analysis of residual cellular content and biomechanical evaluation. Prior to these investigations, we have evaluated safety and efficacy of the given material and the xenoantigens removal. The primary task was to ensure the safety and tissue tensile strength of decellularized pericardium. The second task was to achieve maximum removal of all antigenic components.

Preparation of Bovine Pericardium. We collected the bovine pericardium from $12-$ 18 months age bulls at "Antonovsky Meat Factory" LLC upon the slaughter. All animals underwent veterinary examination. During the process of organ removal, the rules of asepsis were followed with the maximum available atraumaticity, and with anatomical features of the animals been taken into account. All manipulations with animal were performed in accordance with the bioethical standards specified in the Manual for the Care and Use of Laboratory Animals published by the National Institutes of Health (National Institute of Public Health № 85-23, revised in 1985) and in the European convention for protection of vertebrate animals (Council of Europe, Strasbourg, 1986). Excised material was stored 
in a Hank's Balanced Salt Solution (HBSS) at $4{ }^{\circ} \mathrm{C}$ temperature and transported to the laboratory. In 3 hours, bovine pericardium was dissected with removing the external fat. The tissue samples were harvested in $1000 \mathrm{~mL}$ distilled water for three more hours at $4{ }^{\circ} \mathrm{C}$ with constant shaking (70 rpm). It was important to change water every 15 minutes. Bovine pericardium sac was cut into $40 \times 40 \mathrm{~mm}$ samples. Aseptic conditions were provided at all stages of the investigation.

Decellularization procedures. Basing on the literature review, five different decellularization protocols were applied. All samples $40 \times 40 \mathrm{~mm}$ were exposed to the osmotic shock, rinsed with $4{ }^{\circ} \mathrm{C}$ distilled water accompanied continuous stirring at $200 \mathrm{rpm}$ for 72 hours. The distilled water was changed every 6-8 hours.

Ammonium Hydroxide - Triton X-100. The first group of bovine pericardium samples decellularization included the following steps: (1) insertion of pericardium sample $40 \times 40 \mathrm{~mm}$ into $200 \mathrm{~mL}$ bottle, containing $100 \mathrm{ml}$ of $2 \%$ Triton X-100 (Sigma-Aldrich, USA) and 0.2\% Ammonium Hydroxide (Sigma-Aldrich, USA), (2) constant shaking (200 rpm) for 30 days at $4{ }^{\circ} \mathrm{C}[4,5]$.

Triton X-100 and $0.2 \%$ Ammonium Hydroxide and $1 \%$ SDS. The decellularization of second group of bovine pericardium samples included: (1) insertion of pericardium sample $40 \times 40 \mathrm{~mm}$ into the $200 \mathrm{~mL}$ bottle, containing $100 \mathrm{ml}$ of $2 \%$ Triton X-100 (SigmaAldrich, USA) and $0.2 \%$ Ammonium Hydroxide (Sigma-Aldrich, USA) and $1 \%$ SDS (Sigma-Aldrich, USA), (2) constant shaking $(200 \mathrm{rpm})$ for 30 days at $4{ }^{\circ} \mathrm{C}[4,5]$.
$1 \%$ SDS. The third group of samples was decellularized in the following way: (1) sample of pericardium $40 \times 40 \mathrm{~mm}$ was placed into the $200 \mathrm{~mL}$ bottle, containing $100 \mathrm{ml}$ of $1 \%$ SDS (Sigma-Aldrich, USA) (2) with constant shaking $(200 \mathrm{rpm})$ for 30 days at $25^{\circ} \mathrm{C}[5,6]$. Cell lysis solution was changed once a day.

Trypsin enzyme $-1 \%$ SDS. The fourth group of samples of bovine pericardium was decellularized as follows: (1) sample of pericardium $40 \times 40 \mathrm{~mm}$ was placed into the $200 \mathrm{~mL}$ bottle, containing $100 \mathrm{ml} 0.25 \%$ Trypsin - EDTA solution (Sigma-Aldrich, USA) and $1 \%$ SDS (Sigma-Aldrich, USA) (2) with constant shaking $(200 \mathrm{rpm})$ for 30 days at $4{ }^{\circ} \mathrm{C}[7,8]$.

$0,1 \%$ SDS. The fifth group of bovine pericardium samples was decellularized as follows: (1) sample of pericardium $40 \times 40 \mathrm{~mm}$ was placed into the $200 \mathrm{~mL}$ bottle, containing $100 \mathrm{ml} \mathrm{0,1} \%$ SDS (Sigma-Aldrich, USA) with (2) constant shaking (200 rpm) for 40 days at $4{ }^{\circ} \mathrm{C}[6,16,9,10]$.

Cell lysis solution was changed once a day at all protocols.

Histology staining (DAPI and HematoxylinEosin). Hematoxylin - Eosin.

Histopathological examination of the tissue samples included fixation in $10 \%$ neutral buffered formalin ( $\mathrm{pH}$ 7.4) for at least 3 days at $4{ }^{\circ} \mathrm{C}$. The frozen tissues were fixed after snapfreezing and sectioning with a cryostat (thickness of $6 \mu \mathrm{m}$ ).

Validation of the cell nuclei removal was performed according to a standard hematoxylin and eosin (H\&E) staining protocol. The stained samples were examined with Olympus BX 51 light microscope. 
DAPI. DAPI (4',6-diamidino-2- phenylindole, dihydrochloride) staining was performed directly via incubation of a tissue sample (luminal side facing upwards) with $25 \mu \mathrm{g} / \mathrm{mL}$ DAPI, diluted in PBS for 2 min (in the dark). Achieving the maximum thickness of tissue, adventitia and medium layer were removed via using the approach, suggested by Jelev et al. [11]. ECM was fixed on a plate with forceps under a microscope. Intima layer was carefully removed by stretching it with forceps along with simultaneous cutting on the edges with a scalpel, followed by recovery in PBS. DAPI stains were also applied on paraffinembedded cross sections ( $5 \mu \mathrm{m}$ thickness), following standard protocols of fixation, dehydration, embedding, cutting, deparaffinization, rehydration and staining.

DNA quantification. DNA was extracted using the DNA easy Blood and Tissue kit (Qiagen, Germany).

10-25 mg tissue from both initial materials prior to decellularization and decellularized samples were treated with proteinase K briefly to quantify the total amount nucleic acid in $\mathrm{ng} / \mathrm{mg}$ of dry tissue and to calculate the percentage of DNA removal after decellularization. Fluorescence measurements (photons per second) were performed at ambient room temperature, $23-24{ }^{\circ} \mathrm{C}$, using a Qubit 3.0 photon counting spectrofluorometer. The detection limit of DNA was $0.2 \mathrm{ng} / \mu \mathrm{g}$.

Biomechanical tests. We tested five different protocols of decellularization for bovine pericardial ventral surface sac using the 40x40 mm samples for mechanical analysis. All pericardium patches were loaded separately between 2 steel rods and clamped vertically into the testing machine (IMADA,
MX2 - 110, Japan) to measure maximum tensile strength (Fmax). Force was applied until failure with a rate of $60 \mathrm{~cm} / \mathrm{min}$.

Statistical analysis. Descriptive statistics (n, mean, SD, SE, median, minimum, and maximum) was provided. Statistical significance was analyzed using analysis of variation and t-tests as appropriate. $\mathrm{P}$ value $<0.05$ was regarded as statistically significant [12, 13]. Variation and statistical processing of obtained results were performed via StataIC software. Exact testing for categorical variables and Wilcoxon two-sample rank sum test for continuous variables was used to evaluate the differences in baseline variables between groups.

\section{Results and Discussion}

Decellularization is a technique used to decrease antigenicity, thereby reducing subsequent graft rejection and host allosensitization. Numerous protocols of removing cells from tissue have been described [5, 14, 15] for chemical, physical, or combinative methods. There are several most useful protocols of decellularization which include hypotonic cell lysis, detergent and enzymatic extractions with multiple washings, mechanical stripping, and tissue fixation $[9,16]$. The assignment of fundamental and ideal decellularization method is to remove all antigenic components (nucleic acids, cell membranes, cytoplasmic structures, lipids and soluble matrix) from the tissue without damaging the structure and integrity of extracellular matrix [14]. However, several restrictions such as low rate of engraftment and poor survival of stem/progenitor cells after transplantation are crucially important and have to be examined. The primary ex- 
pected outcome of these protocols was assessment of cell removal and mechanical properties of the final tissue. The most common techniques, used for pericardium decellularization, are summarized in Table 1.

Interestingly, a significant effect regarding safety and efficacy was achieved in in vivo experiments with subcutaneous implantation of decellularized pericardium to laboratory animals. The decrease in immunogenicity, reduction of cytotoxicity and graft integration improvement were observed in contrast to the usage of the fresh/frozen or glutaraldehydefixed implanted tissue [15, 17].

Sareh Rajabi-Zeleti et. al. have developed a pericardium-derived scaffold that mimics the natural myocardial extracellular environment and investigated its properties for cardiac tissue engineering. Human pericardium membranes were decellularized. Interestingly, histological examination of subcutaneous transplanted scaffolds after one month revealed low immunological response, enhanced angiogenesis and cardiomyocyte differentiation in pericardium scaffolds compared to the decellularized pericardium membranes and collagen scaffolds [18-20].
Despite great amount of benefits the main concern regarding the most applicable and safe protocols of decellularization still exists. In order to overcome the restrictions, basic research is actively pursuing protocols, aimed at enhancing pericardial tissue durability and purity.

Recently, an interest has increased for the usage of low concentration aldehydes for creating chemical bonds between the extracellular matrix components and preventing the acute immune rejection. At the same time, the aldehyde method has some drawbacks regarding the tissue long-term durability [21]. We have to admit, that the glutaraldehyde technology has appeared unable to remove animal-specific antigens (a1, 3)-Gal epitope [22].

Basing on previous studies, GodierFurnémont et al. [23] designed the scaffold using human mesenchymal progenitor cells, which were embedded into fibrin hydrogel, loaded onto the decellularized myocardium sheets. As a result, the given scaffold played a role of biomechanical support, whereas fibrin enabled the cell retention and local signaling.

The coating of acellular cardiac ECM with electro spun poly-(L)lactic acid/polycaprono-

Table 1. The pericardium decellularization techniques

\begin{tabular}{|c|c|c|c|}
\hline Detergent & Mechanism & Significant effects & Treatment procedure \\
\hline $\begin{array}{l}\text { Sodium dodecyl } \\
\text { sulfate (SDS) }\end{array}$ & Ionic & $\begin{array}{l}\text { Cytotoxicity microstructure } \\
\text { alteration }\end{array}$ & $\begin{array}{l}10 \mathrm{mM} \text { Tris- } \mathrm{HCl} \text { and protease } \\
\text { inhibitors }+0.1 \% \mathrm{SDS}+50 \mathrm{U} / \mathrm{mL} \\
\text { DNAse and } 1 \mathrm{U} / \mathrm{mL} \text { RNAse } \\
\text { Hypotonic/hypertonic solutions }+ \\
1 \% \mathrm{SDS}\end{array}$ \\
\hline Triton X-100 & $\begin{array}{l}\text { Nonionic (commonly used } \\
\text { with ammonium hydroxide) }\end{array}$ & $\begin{array}{l}\text { Less damage of tissue structure } \\
\text { than in case of ionic surfactants }\end{array}$ & $\begin{array}{l}0.1 \% \text { SDS + Triton X-100+0.1 } \\
\text { mg/mL DNAse }\end{array}$ \\
\hline $\begin{array}{l}\text { Ammonium } \\
\text { hydroxide }\end{array}$ & $\begin{array}{l}\text { Osmotic swelling and } \\
\text { subsequent lysis }\end{array}$ & - & $\begin{array}{l}\text { Acetone }+ \text { Ethanol }+1 \mathrm{~N} \mathrm{NaOH}+ \\
7 \% \mathrm{NaCl}+\mathrm{H}_{2} \mathrm{O}_{2}\end{array}$ \\
\hline
\end{tabular}


lactone/collagen nanofibers should also be mentioned. This approach was previously tested by Guhathakurta et al. and showed several promising advantages [24]. They created a myocardial patch, exhibiting the contractile activity and the expression of specific troponin I and cardiac myosin during in vitro culturing. The experimental data are rather controversial, and there is no general agreement about the unified approach to decellularization of pericardium. It was noted that one of the biggest challenges is to discover the best method of obtaining intact scaffolds. Each of above mentioned protocols and studies has numerous advantages, but the cost effectiveness and manufacturing capacities constitute a great concern.

In this study, we compared five protocols of bovine pericardium decellularization, which could be potentially used in cardiac surgery.

We noticed that pericardium tissue changed substantially (Fig. 1) in group 3 (1\% SDS at $25^{\circ} \mathrm{C}$ ). Almost all cells were removed after 14 days of exposure. The previous studies have shown similar results particularly no basophilic purple staining after cells removal from tissue confirmed by H\&E staining $[5,6]$. Additionally, the absence of relevant DAPI staining confirmed that most of the cellular nuclear material disappeared after emulsification with the detergent. This could be clearly visualized by microscopy examination of the stained H/E and DAPI samples (Fig. 2). At the same time, we observed the absence of nuclear elements and the preservation of the matrix structure in the group 4 with the same time of exposure. In group 5, the effect was observed after 21 days of processing (decellularization). For groups 1 and 2 we the absence and lack of nuclei in H\&E and DAPI stained samples respectively.

Upon cellular debris removal and histological analysis, the DNA assay was performed for the detection of nucleic acids content in ECM samples. The DNA assay showed that at the decellularization processes nucleic acids are removed from ECM, however, the residual content may vary depending on the method applied. Robert Ramm et.al revealed significant differences between the applied decellularization protocols as the clinically approved $\mathrm{SDS} / \mathrm{SD}$ protocol was unable to remove DNA, whereas the combined use of Trypsin and TX demonstrated high efficacy [7]. The same result was obtained for group 4 (Trypsin enzyme $+1 \%$ SDS), where the fastest removal of the nucleic acid residues was demonstrated (Fig. 3). Finally, the results suggest that the group 5 samples showed the lowest nucleic acids concentration after 28 days of the decellularization process.

As a result of our investigation, we observed the lowest level of the tissue tensile strength in the group 3 samples (Fig. 4). Therefore, the decellularization treatments, based on a single-step detergent or enzyme (0.5\% SDS, $1 \%$ Triton X-100, and $0.5 \%$ trypsin), share broad abilities disrupt the collagen crimp structure, as described by Liao et al [8, 25]. All other used approaches for decellularization ensured more appropriate biomechanical properties. The tissue tensile strength values in the group 1 and 2 samples were approximately the same, but in 1,54 and 1,79 times lower than in the control group respectively $(p<0,05)$. Noteworthy, we stopped the decellularization in the group 1 and 2 samples after 42 days of processing. The concen- 

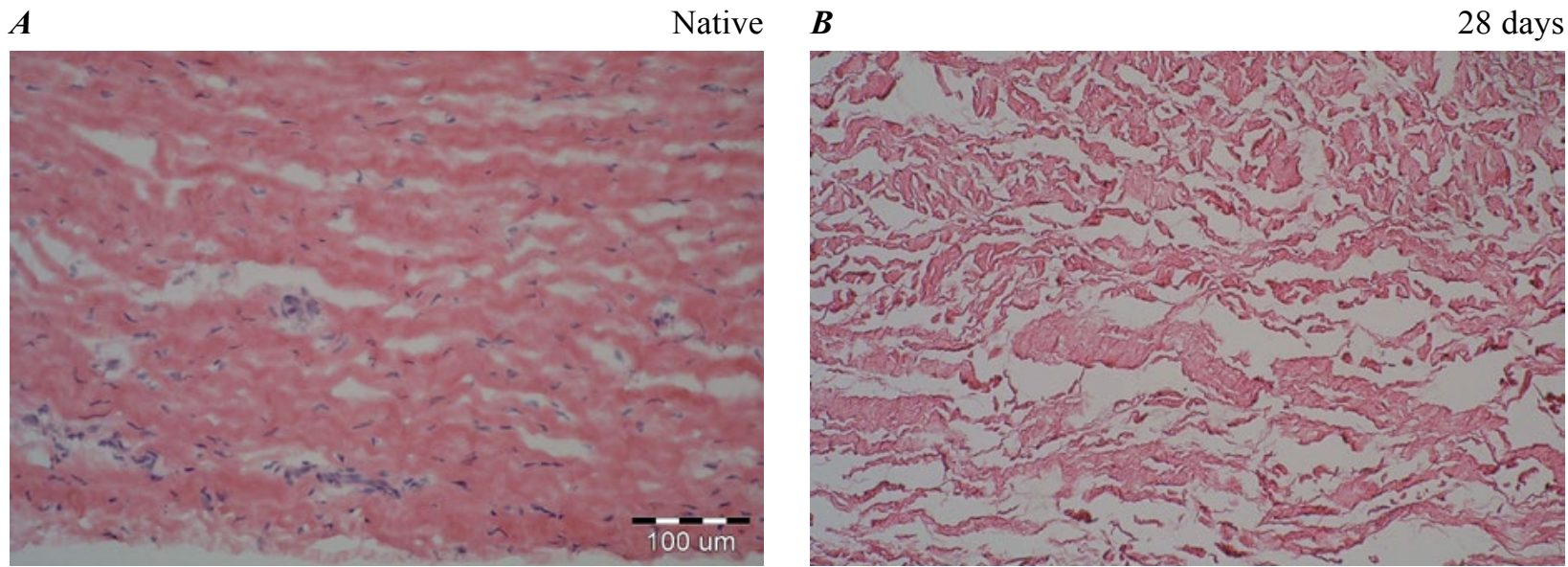

C

28 days

$\boldsymbol{D}$

14 days
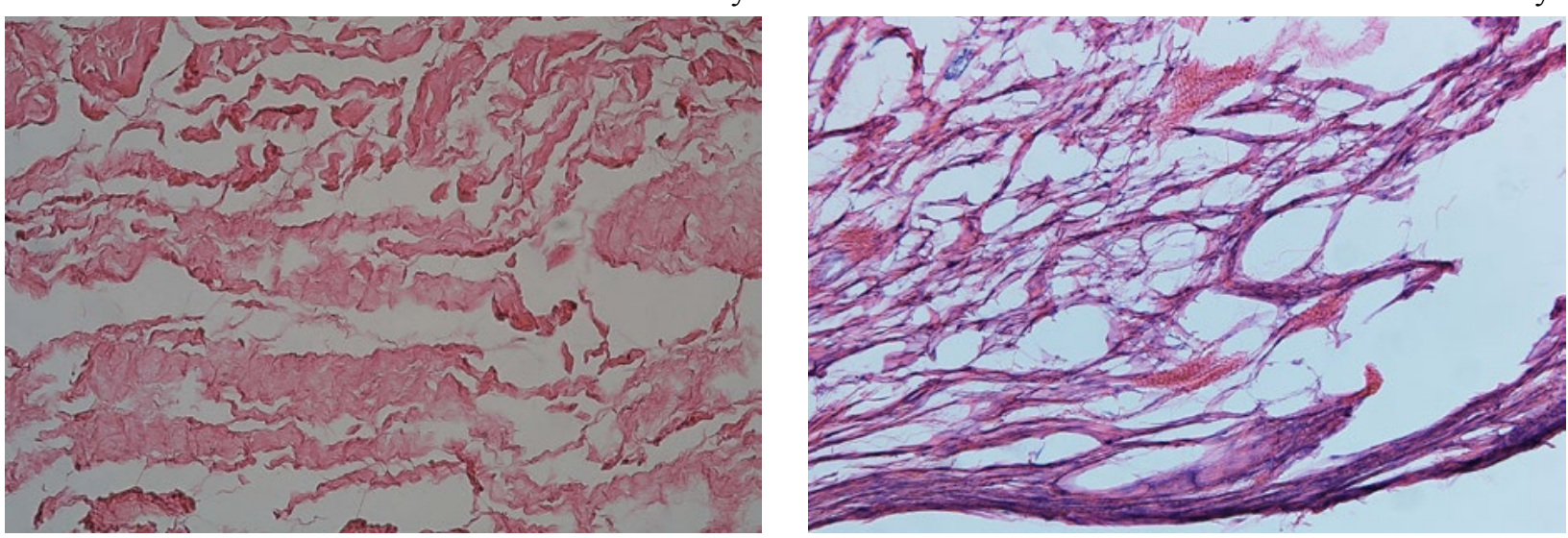

$\boldsymbol{E}$

14 days

$\boldsymbol{F}$

21 days
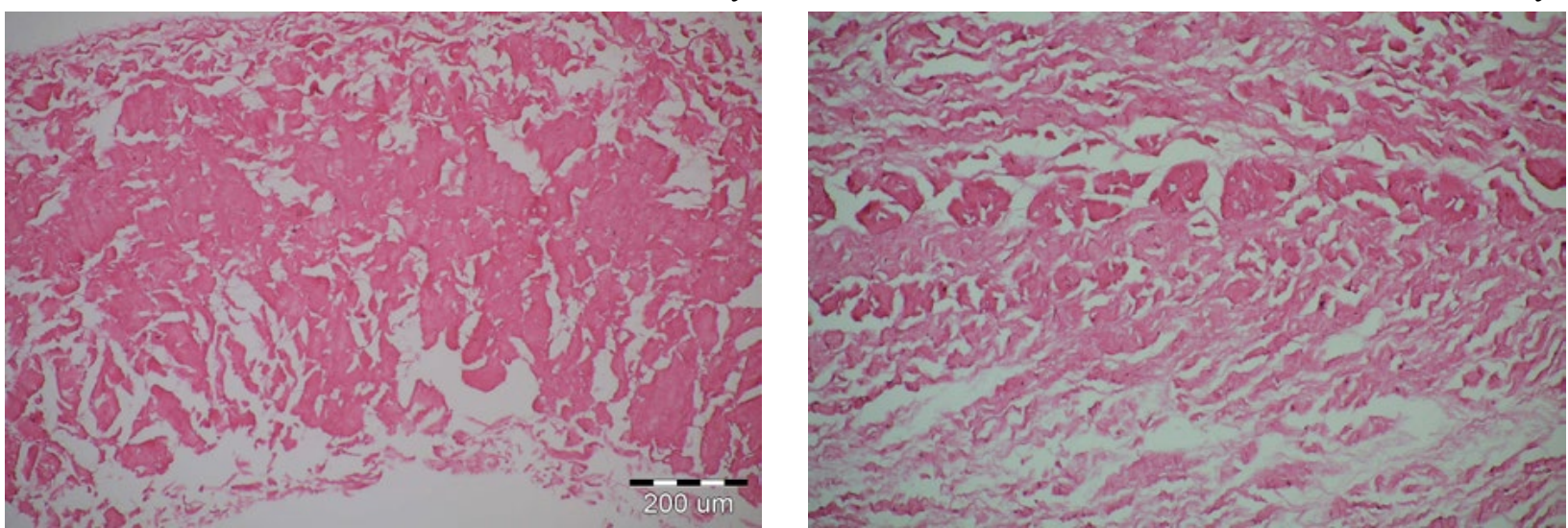

Fig. 1. Histological specimens of pericardium after different protocols of decellularization (H/E staining). $A-n a t i v e$ pericardium; B -Ammonium Hydroxide + Triton X-100; C-1\% SDS + Ammonium Hydroxide + Triton X-100; D $1 \%$ SDS; E- Trypsin enzyme $+1 \%$ SDS; F-0,1\% SDS 
A

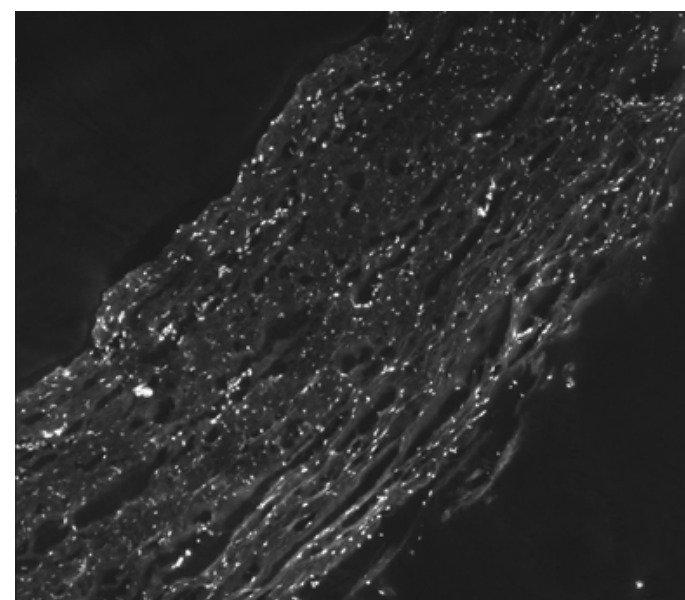

C

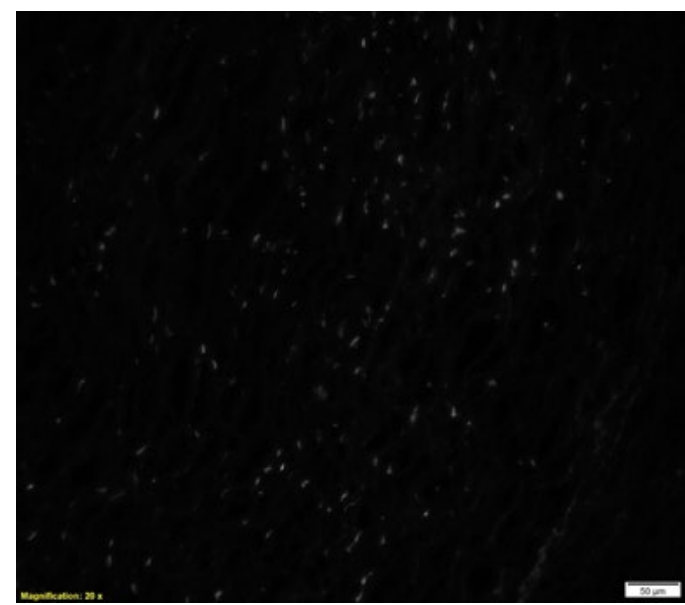

E
B

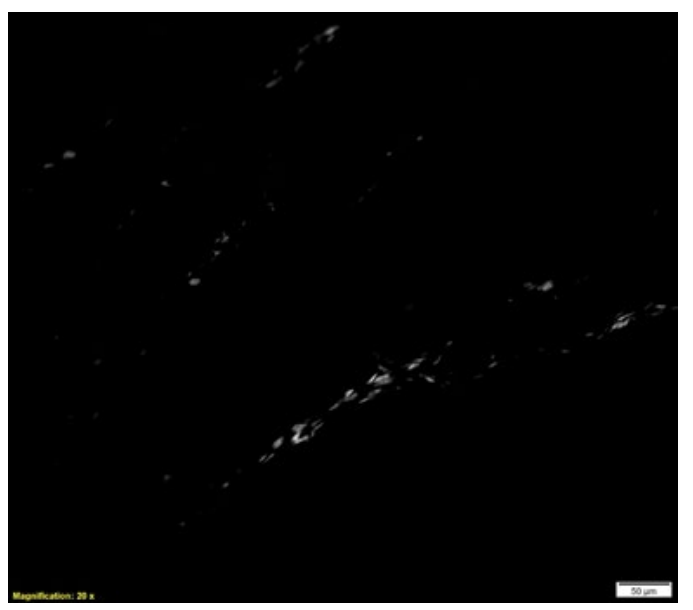

D

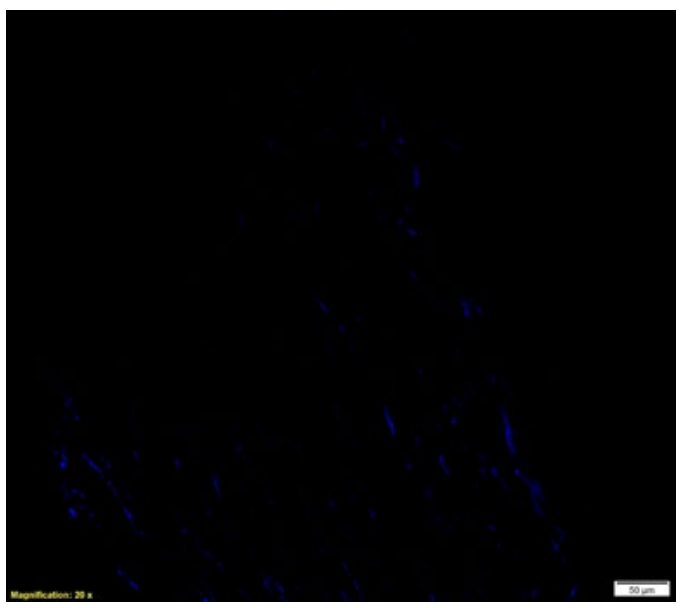

F

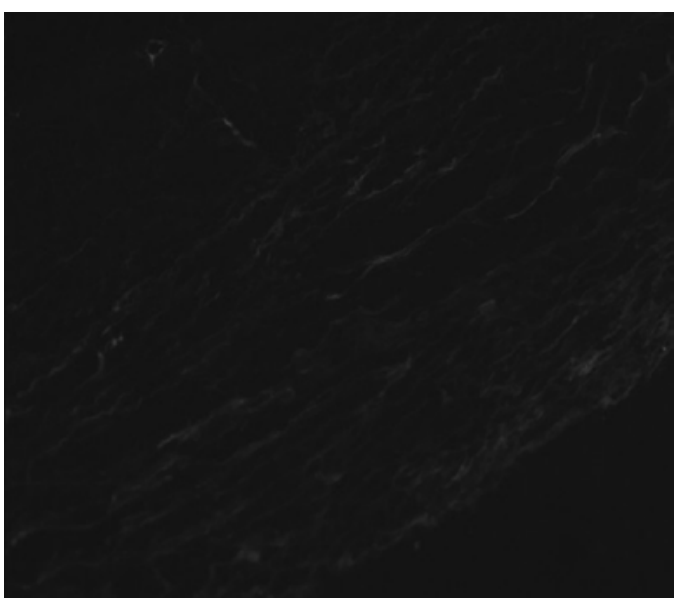

Fig. 2. Histological specimens of pericardium after different protocols of decellularization (DAPI staining). $A-$ native pericardium; $B$ - Ammonium Hydroxide + Triton X-100; C-1\% SDS + Ammonium Hydroxide + Triton X-100; D $\%$ SDS; $E-$ Trypsin enzyme $+1 \%$ SDS; $F-0,1 \% S D S$. 

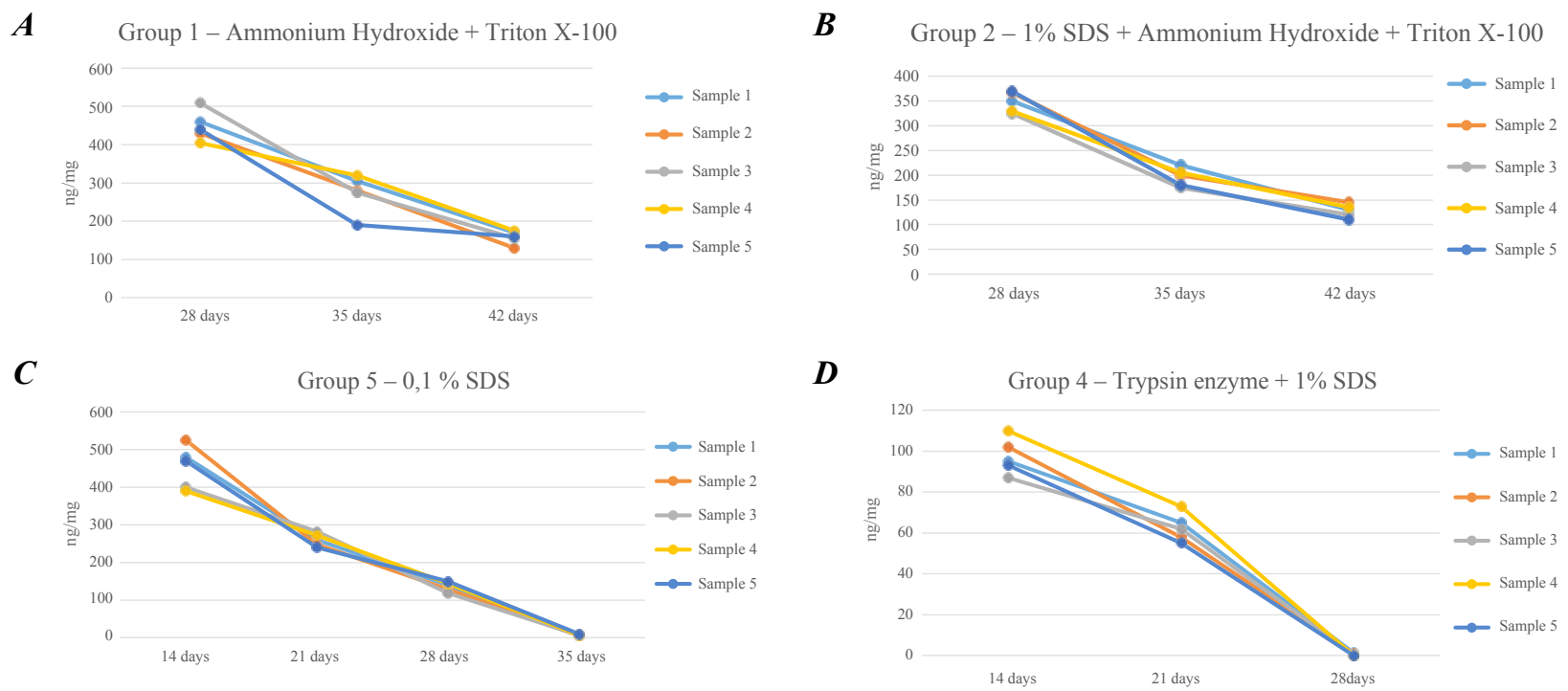

Fig. 3. DNA concentrations (ng/ $\mu \mathrm{g})$ in the pericardium samples of Group $1-T X+A D$; Group $2-T X+A D+1 \% S D S$; Group $3-$ TRIPSYN+1\% SDS; Group 4-0,1\% SDS; error bars represent means $\mathrm{x} \pm \mathrm{SE}$; * $-\mathrm{P}<0.05$.

tration of nucleic acids in ECM was quite high and the samples needed further exposure to detergents, even after such long time of removing cells. Kasimir MT et. al. consider that long time detergents exposure is able to destabilize the collagen triple helical domain and to pro- voke swelling of elastin network [26]. Also, we have to admit, that the group 4 and 5 samples have shown the highest $\mathrm{F}_{\max }$ levels $(p<0,05)$, that may be associated with a less prolonged exposure to the decellularized solutions. The values of the maximum tensile

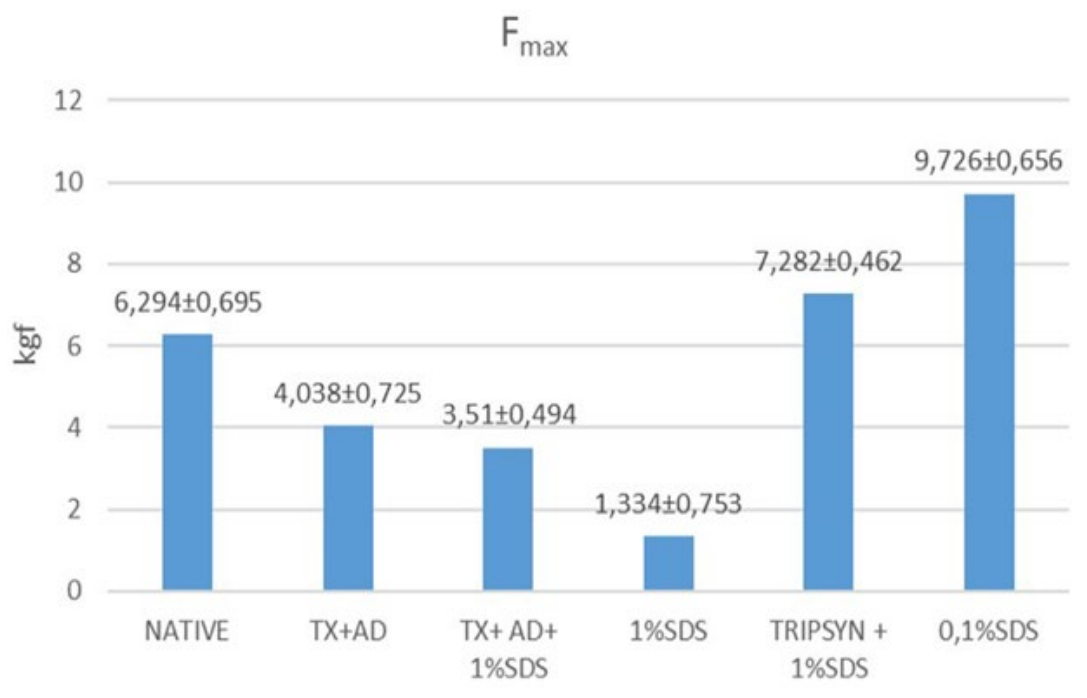

Fig. 4. Dependence of the maximum tensile strength (Fmax) of bovine pericardium on the protocol of decellularization, error bars represent means $\mathrm{x} \pm \mathrm{SE} ;{ }^{*}-\mathrm{P}<0.05$. 
strength in the group 4 and 5 samples were in 1,15 and 1,51 times higher than in the control group respectively.

Thus, the covariant effect should be taken into consideration, depending on the tissue cellularity (eg. liver vs cartilage), density (eg. heart valves vs adipose tissue), lipid content (eg. brain vs urinary bladder), and thickness (eg, dermis vs pericardium), for the successful xenogeneic tissues decellularization. Ideally, both ECM architecture and mechanical properties of a graft should minimally be affected the decellularization [8, 27, 28].

\section{Conclusion}

The data of histological and biomechanical testing have shown that $0,1 \%$ SDS and Trypsin enzyme $-1 \%$ SDS protocols are optimal for the procedure of decellularization due to a faster removal of cells and a better preservation of tissue tensile strength level. They may be appropriate protocols for further (collagenelastin matrix modification and stabilization processing) studying and producing a suitable material for heart tissue engineering.

\section{REFERENCES}

1. Mallis P, Michalopoulos E, Dimitriou C, Kostomitsopoulos N, Stavropoulos-Giokas C. Histological and biomechanical characterization of decellularized porcine pericardium. Bio-Medical Materials and Engineering. 2017; 28:477-488.

2. Lima EO, Ferrasi AC, Kaasi A. Decellularization of Human Pericardium with Potential Application in Regenerative Medicine. Arquivos brasileiros de cardiologia. 2019;113(1):18-19.

3. Gonçalves A, Griffiths L, Christopher RO. Decellularization of bovine pericardium for tissue-engineering by targeted removal of xenoantigens. The Journal of heart valve disease. 2005;14:212-7.
4. J Koudy Williams, Elizabeth S Miller, Magan $R$ Lane, Anthony Atala, James $J$ Yoo, James E Jordan. Characterization of CD133 Antibody-Directed Recellularized Heart Valves. J Cardiovasc Transl Res. 2015 Oct;8(7):411-20. doi: 10.1007/s12265-0159651-3.

5. Simões IN, Vale P, Soker S, Atala A, Keller D, Noiva R, Carvalho S, Peleteiro C, Cabral JMS, Eberli D, da Silva CL, Baptista PM. Acellular Urethra Bioscaffold: Decellularization of Whole Urethras for Tissue Engineering Applications. Scientific Reports. 2017;7(41934).

6. White LJ, Taylor AJ, Faulk DM, Keane TJ, Saldin LT, Reing JE, Swinehart IT, Turner NJ, Ratner BD, Badylak SF. The impact of detergents on the tissue decellularization process: a ToF-SIMS study. Acta Biomater. 2017;50:207-219.

7. Ramm R, Goecke T, Theodoridis K, Hoeffler K, Sarikouch S, Findeisen K, Ciubotaru A, Cebotari S, Tudorache I, Haverich A, Hilfiker A. Decellularization combined with enzymatic removal of $\mathrm{N} \square$ linked glycans and residual DNA reduces inflammatory response and improves performance of porcine xenogeneic pulmonary heart valves in an ovine in vivo model. Xenotransplantation. 2019;27(1). DOI: 10.1111/xen.12571.

8. Naso F, Alessandro G. Different approaches to heart valve decellularization: A comprehensive overview of the past 30 years. 2017. DOI: 10.1111/xen.12354.

9. Schaner PJ, Martin ND, Tulenko TN, Shapiro IM, Tarola NA, Leichter RF, et al. Decellularized vein as a potential scaffold for vascular tissue engineering. J Vasc Surg. 2004;40:146-153.

10. Simsa R, Manikantan Padma A, Heher P, Hellström M, Teuschl A, Jenndahl L, Bergh N, Fogelstrand $P$, Soncini $M$. Systematic in vitro comparison of decellularization protocols for blood vessels. Acta Biomater. 2017;50:207-219.

11. Jelev L, Surchev L. A novel simple technique for en face endothelial observations using water-soluble media -'thinned-wall' preparations. J Anat. Wiley-Blackwell. 2008;212:192-7. 10.1111/ j.14697580.2007 .00844$.

12. Amrhein $V$, Korner-Nievergelt $F$, Roth $T$. The earth is flat $(\mathrm{p}>0.05)$ : significance thresholds and the 
crisis of unreplicable research. The Journal of Life and Environmental Sciences. 2017;5:e3544. doi: $10.7717 /$ peerj.3544

13. Colquhoun D. The reproducibility of research and the misinterpretation of p-values. Royal Society Open Science. 2017;4(12): 171085. doi:10.1098/ rsos. 171085.

14. Rippel RA, Ghanbari H, Seifalian AM. Tissue-engineered heart valve: future of cardiac surgery. World J Surg. 2012;36(7):1581-91;

15. Wilcox HE, Watterson KG, Kearney JN, Hunt J, Fisher J, Ingham E. Biocompatibility of acellular human pericardium. J. Surg. Res. 2007;143:407-414.

16. Nesteruk I, Pereverzyev S Jr., Mayer L, Steiger R, Kusstatscher L, Fritscher K, Knoflach M, Gizewsk ER. Stenosis detection in internal carotid and vertebral arteries with the use of diameters estimated from MRI data. Innov Biosyst Bioeng. 2019;4(3):131-142.

17. Van Steenberghe M, Schubert T, Guiot Y, Bouzin C, Bollen X, Gianello P. Enhanced vascular biocompatibility of decellularized xeno-/allogeneic matrices in a rodent model. Cell Tissue Bank. 2017;18:249-262.

18. Rajabi-Zeleti S, Jalili-Firoozinezhad S, Azarnia M, Khayyatan F, Vahdat S, Nikeghbalian S, Khademhosseini A, Baharvand H, Aghdami N. The behavior of cardiac progenitor cells on macroporous pericardium-derived scaffolds. Biomaterials. 2014;35:970-982.

19. Douglas JF, Gaughran ER, Henderson J, Lord GH, Rosenberg $N$. The use of arterial implants prepared by enzymatic modification of arterial heterografts. II. The physical properties of the elastica and collagen components of the arterial wall. AMA Arch Surg. 1957;74:89-95.

20. Hoch J, Jarrell BE, Schneider T, Williams SK. Endothelial cell interactions with native surfaces. Ann Vasc Surg. 1989;3:153-159.

21. Shang H, Claessens SM, Tian B, Wright GA. Aldehyde reduction in a novel pericardial tissue reduces calcification using rabbit intramuscular model. Journal of materials science. Materials in medicine. 2017;28(1):16. https://doi.org/10.1007/ s10856-016-5829-8.
22. Huai G, QiP, Yang H, Wang Y. Characteristics of $\alpha$-Gal epitope, anti-Gal antibody, $\alpha 1,3$ galactosyltransferase and its clinical exploitation (Review). International journal of molecular medicine. 2016;37(1):11-20. https://doi.org/10.3892/ ijmm.2015.2397.

23. Martens TP, Koeckert MS, Wan L, Parks J, Arai K, Zhang G, Hudson B, Homma S, Vunjak-Novakovic $G$. Composite scaffold provides a cell delivery platform for cardiovascular repair. Proc. Natl. Acad. Sci. USA. 2011;108:7974-7979.

24. Guhathakurta S, Mathapati S, Bishi D K, Rallapalli $S$, Cherian KM. Nanofiber-reinforcedmyocardial tissue-construct as ventricular assist device. Asian Cardiovasc. Thorac. Ann. 2014;22:935-943.

25. Liao J, Joyce EM, Sacks MS. Effects of decellularization on the mechanical and structural properties of the porcine aortic valve leaflet. Biomaterials. 2008;29:1065-1074.

26. Kasimir MT, Rieder E, Seebacher G, Silberhumer $G$, Wolner E, Weigel G, Simon P. Comparison of different decellularization procedures of porcine heart valves. Int J Artif Organs. 2003;26:421-427.

27. Herheliuk T, Perepelytsina O, Ostapchenko L, Sydorenko $M$. Effect of interferon $\alpha-2 b$ on multicellular tumor spheroids of MCF-7 cell line enriched with cancer stem cells. Innov Biosyst Bioeng, 2019; 3(1): 34-44.

28. Lutsenko TN, Kovalenko MV, Galkin OY. Validation of biological activity testing procedure of recombinant human interleukin-7. Ukr. Biochem. J. 2017; 89(1):82-89.

\section{Порівняльне дослідження різних способів децелюляризації перикарда великої рогатої худоби для виготовлення кардіохірургірургічних біоматеріалів}
А. А. Сокол, Д. А. Греков, Г. І. Смець, О. Ю. Галкін, Н. В. Щоткіна, А. А. Довгалюк, О. В. Телегузова, Н. М. Руденко, О. М. Романюк, I. М. Смець

Мета. Визначення найбільш ефективних протоколів децелюляризації. Методи. Перикард великої рогатої худоби децелюляризували за п'ятьма протоколами: Група 1 -Ammonium Hydroxide + Triton X-100, Група 
$2-1 \%$ SDS + Ammonium Hydroxide - Triton X-100, Група 3 - $1 \%$ SDS, Група 4 - Trypsin enzyme $+1 \%$ SDS, Група 5 - 0,1 \% SDS, відповідно. Оцінка методів проводилась за даними гістологічного, біомеханічного та ДНК тестів. Результати. Час децелюляризації Групи 1 і 2 набагато довші, ніж описано в попередніх рукописах, біомеханічні показники нижчими ніж у нативних зразках. Найнижчі показники спостерігали у зразків Групи 3, де незважаючи на майже повне видалення клітин із тканин, біомеханічні властивості волокон були втрачені. Зразки груп 4 і 5 мають високу міцність тканини на розтяг, відсутність нуклеїнової кислоти через 21 день децеллюляризації. Висновки. Дані гістологічних, біомеханічних та ДНК-тестів показали, що протоколи з використанням $0,1 \%$ SDS та Trypsin $+1 \%$ SDS є оптимальними для децелюляризації.

К л ю ч о в і с л о в а: перикард, децелюляризація, $m \kappa a-$ нинна інженерія

\section{Сравнительное исследование различных} способов децелюляризации перикарда крупного рогатого скота для изготовления кардиохирургирургичних биоматериалов

А. А. Сокол, Д. А. Греков, Г. И. Емец, А. Ю. Галкин, Н. В. Щеткина, А. А. Довгалюк, А. В. Телегузова, Н. Н. Руденко, А. Н. Романюк, И. Н. Емец
Цель. Определение наиболее эффективных протоколов децелюляризации. Методы. Децеллюляризация перикарда большого рогатого скота проводилась по пяти протоколам: Группа 1 - Ammonium Hydroxide + Triton X-100, Группа 2 - 1 \% SDS + Ammonium Hydroxide Triton X-100, Группа 3 - 1 \% SDS, Группа 4 - Trypsin enzyme $+1 \%$ SDS, Группа $5-0,1 \%$ SDS, соответственно. Оценка методов проводилась по данным гистологического, биомеханического и ДНК тестов. Результаты. Время децеллюляризации Группы 1 и 2 гораздо длиннее, чем описано в научной литературе, а биомеханические показатели ниже, чем в контрольных образцах. Самые низкие показатели наблюдались у образцов Группы 3, где несмотря на почти полное удаление клеток из тканей, биомеханические свойства волокон были потеряны. Образцы групп 4 и 5 имеют высокую прочность ткани на растяжение, отсутствие нуклеиновой кислоты через 21 день децеллюляризации. Выводы. Данные гистологических, биомеханических и ДНК-тестов показали, что протоколы с использованием 0,1 \% SDS и Trypsin +1 \% SDS являются оптимальными для децелюляризации.

К л юч е в ы е с л о в а: перикард, децеллюляризация, тканевая инженерия

Received 20.08.2020 